\title{
Short communication: Relationship between lysine/methionine ratios and glucose levels and their effects on casein synthesis via activation of the mechanistic target of rapamycin signaling pathway in bovine mammary epithelial cells
}

\author{
F. Wang, ${ }^{1}$ J. van Baal, ${ }^{2}$ L. Ma, ${ }^{1}$ J. J. Loor, ${ }^{3}$ Z. L. Wu, ${ }^{4}$ J. Dijkstra, ${ }^{2}$ and D. P. Bu ${ }^{1,5,6 *}$ \\ ${ }^{1}$ State Key Laboratory of Animal Nutrition, Institute of Animal Science, Chinese Academy of Agricultural Sciences, Beijing, 100193, P.R. China \\ ${ }^{2}$ Animal Nutrition Group, Wageningen University and Research, Wageningen, 6708 WD, the Netherlands \\ ${ }^{3}$ Department of Animal Sciences and Division of Nutritional Sciences, University of Illinois, Urbana 61802 \\ ${ }^{4}$ State Key Laboratory of Animal Nutrition, China Agricultural University, Beijing, 100193, P.R. China \\ ${ }^{5}$ CAAS-ICRAF Joint Lab on Agroforestry and Sustainable Animal Husbandry, World Agroforestry Centre, East and Central Asia, Beijing, 100081, \\ P.R. China \\ ${ }^{6}$ Hunan Co-Innovation Center of Animal Production Safety, Changsha, Hunan, 410128, P.R. China
}

\section{ABSTRACT}

The synthesis of protein requires the availability of specific AA and a large supply of energy in bovine mammary epithelial cells (BMEC). Whether an interaction exists between Lys/Met ratio and glucose level on milk protein synthesis and its potential regulatory mechanism is unclear. We investigated the effects of different Lys/Met ratios and glucose levels on casein synthesis-related gene expression in BMEC to elucidate the underlying molecular mechanisms. Primary BMEC were subjected to 4 treatments for $36 \mathrm{~h}$, arranged in a $2 \times 2$ factorial design with Lys/Met ratios of 3:1 (1.2:0.4 $\mathrm{mM}$, LM3.0; total AA $=8.24 \mathrm{mM})$ and 2.3:1 (1.4:0.6 $\mathrm{m} M$, LM2.3; total AA $=8.64 \mathrm{~m} M$ ) and glucose levels of $17.5 \mathrm{~m} M$ (high glucose level) and $2.5 \mathrm{~m} M$ (low glucose level). No interactions between Lys/Met ratio and glucose level on cell viability, cell cycle progression, mRNA, or protein expression levels were found. High glucose level increased cell proliferation and promoted cell cycle transition from intermediate phase (G1 phase) to synthesis (S phase) by approximately $50 \%$, whereas Lys/Met ratio had no effect. Both mRNA and protein abundance of $\alpha_{\mathrm{S}_{1}}$-casein and $\beta$-casein were positively affected by LM3.0, whereas a high glucose level increased protein abundance of $\alpha_{\mathrm{S1}}$-casein and $\beta$-casein and increased gene expression of CSN1S1 but not of $C S N 2$. Furthermore, high glucose increased the mRNA abundance of ELF5 and decreased that of GLUT8, enhanced protein expression of total and phosphorylated mechanistic target of rapamycin (mTOR), and decreased phosphorylated AMP-activated protein ki-

Received October 29, 2018.

Accepted May 20, 2019.

*Corresponding author: budengpan@126.com nase (AMPK) levels. Treatment LM3.0 had a stimulatory effect on total and phosphorylated mTOR but did not affect AMPK phosphorylation. The mRNA levels of JAK2, ELF5, and RPS6KB1 were upregulated and mRNA levels of EIF $4 E B P 1$ were downregulated with LM3.0 compared with LM2.3. Our results indicate that casein synthesis was regulated by Lys/Met ratio via JAK2/ELF5, mTOR, and its downstream RPS6KB1 and EIF4EBP1 signaling. In contrast, glucose regulated casein synthesis through promoting cell proliferation, accelerating cell cycle progression, and activating the ELF5 and AMPK/mTOR signaling pathways. Within the range of substrate levels in the present study, a change in Lys/Met ratio had a stronger effect on abundance of $\alpha_{S 1}$-casein and $\beta$-casein than a change in glucose level.

Key words: casein, glucose, amino acid, mammary cell signaling

\section{Short Communication}

Greater N utilization efficiency of dairy cows is associated with an increased utilization of AA by mammary tissue for milk protein synthesis, which leads to reduced AA catabolism by the splanchnic tissues (Hanigan et al., 1998). Milk protein synthesis is a highly active and energetically costly process that requires the availability of AA and a large supply of energy (Reynolds et al., 1994). Among AA, Lys and Met are considered to be potentially limiting EAA for milk protein synthesis (Hanigan et al., 2002; Babar et al., 2009). Therefore, their supplementation may provide an effective approach to balance AA for better milk production (Wang et al., 2010). In general, milk protein synthesis is also stimulated by increasing glucose supply to the mammary gland (Rius et al., 2010). Glucose is highly 
important to intermediary metabolism during lactation because mammary glucose use for lactose, glycerol, and energy purposes is high. Literature characterizing the effects of glucose supply at different levels of AA on mammary gland protein synthesis and $\mathrm{N}$ utilization efficiency in dairy cattle is scarce (Nichols et al., 2019). The janus kinase and signal transducer and activator of transcription (JAK-STAT) and the mechanistic target of rapamycin (mTOR) are 2 crucial signaling pathways controlling milk protein synthesis (Bionaz and Loor, 2011). Understanding the molecular processes underlying the regulation of protein synthesis in mammary cells could help improve the efficiency of dietary protein and energy utilization by targeted changes in nutrient supply. Therefore, the objective of this study was to investigate the effects of combinations of different Lys/ Met ratios and of glucose levels and their interaction on casein synthesis and on gene and protein expression in bovine mammary epithelial cells (BMEC) to elucidate some of the underlying mechanisms. We hypothesized that, given different signaling pathways controlling milk casein synthesis, the effect of Lys/Met ratio and glucose level would be additive.

Mammary gland tissues were obtained from 1 Holstein dairy cow in mid lactation killed at a commercial abattoir (Harbin, China). The details regarding establishment of the BMEC culture are described by $\mathrm{Hu}$ et al. (2009). Briefly, cells were cultured in Dulbecco's modified Eagle's medium (DMEM) and F-12 medium in a ratio of 1:1 and supplemented with $10 \%$ fetal bovine serum (FBS; serum and all media from Gibco, Waltham, MA) in a $5 \% \mathrm{CO}_{2}$ humidified incubator at $37^{\circ} \mathrm{C}$. When the BMEC were at $80 \%$ confluence, the FBS-containing medium was replaced with FBS-free medium and the cells were incubated for $8 \mathrm{~h}$ as an adaptation period.

Treatments were arranged in a $2 \times 2$ factorial design with Lys/Met ratios of 3:1 (1.2:0.4 mM, LM3.0; total $\mathrm{AA}=8.24 \mathrm{~m} M)$ and 2.3:1 (1.4:0.6 $\mathrm{m} M$, LM2.3; total $\mathrm{AA}=8.64 \mathrm{mM}$ ) and glucose levels of $17.5 \mathrm{mM}$ (high glucose level) and $2.5 \mathrm{mM}$ (low glucose level). Of all the combinations of Lys and Met levels evaluated by Nan et al. (2014), the greatest casein concentration in culture medium was obtained at $1.2 \mathrm{~m} M$ Lys and $0.4 \mathrm{~m} M$ Met, whereas the smallest casein concentration was obtained at $1.4 \mathrm{~m} M$ Lys and $0.6 \mathrm{~m} M$ Met. The concentration of Lys used in this work ranged from 5 - to 20 -fold and the concentration of Met ranged from 3- to 24-fold compared with the concentration of Lys and Met in arterial plasma in dairy cows (Hadrová et al., 2012; Nichols et al., 2016). The glucose level was more than 3-fold greater than the concentrations in the arterial blood of the dairy cow (Rius et al., 2010) and was the recommended dose in high-glucose DMEM/F-12 for cell cul- ture from Gibco (Waltham, MA). The treatments were incubated with tailor-made medium (Gibco, based on cat. no. 10565-018 of DMEM/F-12) for $36 \mathrm{~h}$. The medium was completely devoid of Lys, Met, and glucose and contained the following AA $(\mathrm{mg} / \mathrm{L})$ : glycine, 0.25 ; L-alanine, 0.05; L-alanine L-glutamine, 2.50; L-arginine hydrochloride, 0.70 ; L-asparagine $-\mathrm{H}_{2} \mathrm{O}, 0.05$; L-aspartic acid, 0.05; L-cysteine hydrochloride $-\mathrm{H}_{2} \mathrm{O}, 0.10$; Lcystine $2 \mathrm{HCl}, 0.10$; L-glutamic acid, 0.05; L-histidine hydrochloride $-\mathrm{H}_{2} \mathrm{O}, 0.15$; L-isoleucine, 0.42 ; L-leucine, 0.45 ; L-phenylalanine, 0.22; L-proline, 0.15; L-serine, 0.25; L-threonine, 0.45; L-tryptophan, 0.04; L-tyrosine disodium salt hydrate, 0.21 ; and L-valine, 0.45 . There were 3 replicates per treatment.

Cell viability was measured with a Cell Proliferation Reagent WST-1 Kit (Roche, Basel, Switzerland) according to the manufacturer's protocol. Briefly, after $36 \mathrm{~h}$ of incubation at $37^{\circ} \mathrm{C}$, WST-1 $(10 \mu \mathrm{L} /$ well $)$ was added to the medium, and after $4 \mathrm{~h}$ of incubation the absorbance was measured at $450 \mathrm{~nm}$ length. Cell cycle was detected as described in Zhang et al. (2018). Briefly, cells were serum starved for $8 \mathrm{~h}$ and subsequently cultured for $36 \mathrm{~h}$ with 1 of the 4 treatments, washed, resuspended, and loaded into a flow cytometer. The RNA extraction, RNA quality identification, reverse transcription, and real-time PCR were conducted as described previously (Nan et al., 2014). The PCR conditions were as follows: 1 cycle of $30 \mathrm{~s}$ at $95^{\circ} \mathrm{C}$ followed by 40 cycles of $5 \mathrm{~s}$ at $95^{\circ} \mathrm{C}, 34 \mathrm{~s}$ at $60^{\circ} \mathrm{C}$, and $1 \mathrm{~min}$ at $72^{\circ} \mathrm{C}$. As internal standards, expression of normalization genes mitochondrial ribosome associated GTPase 1 (MTG1), ribosomal protein S9 (RPS9), ubiquitously expressed transcript isoform $2(U X T), G A P D H$, and S100 calcium-binding protein A10 (S100A10) were analyzed, and geNorm (Vandesompele et al., 2002) identified UXT and RPS9 as the most stable reference genes across treatments. Primers used are listed in Table 1. Data analysis was performed using the $2^{-\Delta \Delta \mathrm{CT}}$ method (Livak and Schmittgen, 2001) where RPS9 was used as the internal control.

After $36 \mathrm{~h}$ of incubation, cell lysate ( $25 \mu \mathrm{g}$ of protein) was obtained for immunoblot analyses as described by Nan et al. (2014). Membranes were blocked in Trisbuffered saline with Tween-20 containing 5\% skim milk (BD Difco, Franklin Lakes, NJ) or 5\% BSA (Biptopped, Beijing, China). Primary antibodies against $\alpha_{\mathrm{S} 1}$-casein (CSN1S1; Sigma-Aldrich, St. Louis, MO; cat. no. SAB1401093), $\beta$-casein (CSN2; Abcam, Cambridge, UK; cat. no. ab112595), mTOR (ImmunoWay Biotechnology Co., Plano, TX; cat. no. YT2913), phosphorylated mTOR ( $\mathrm{Ser}^{2448}$; ImmunoWay Biotechnology Co., cat. no. YP1134), AMP-activated protein kinase (AMPK; ImmunoWay Biotechnology Co., cat. no. YT0216) or phosphorylated AMPK ( $\mathrm{Thr}^{183 / 172}$; 
Table 1. Primer sequences used for real-time quantitative PCR

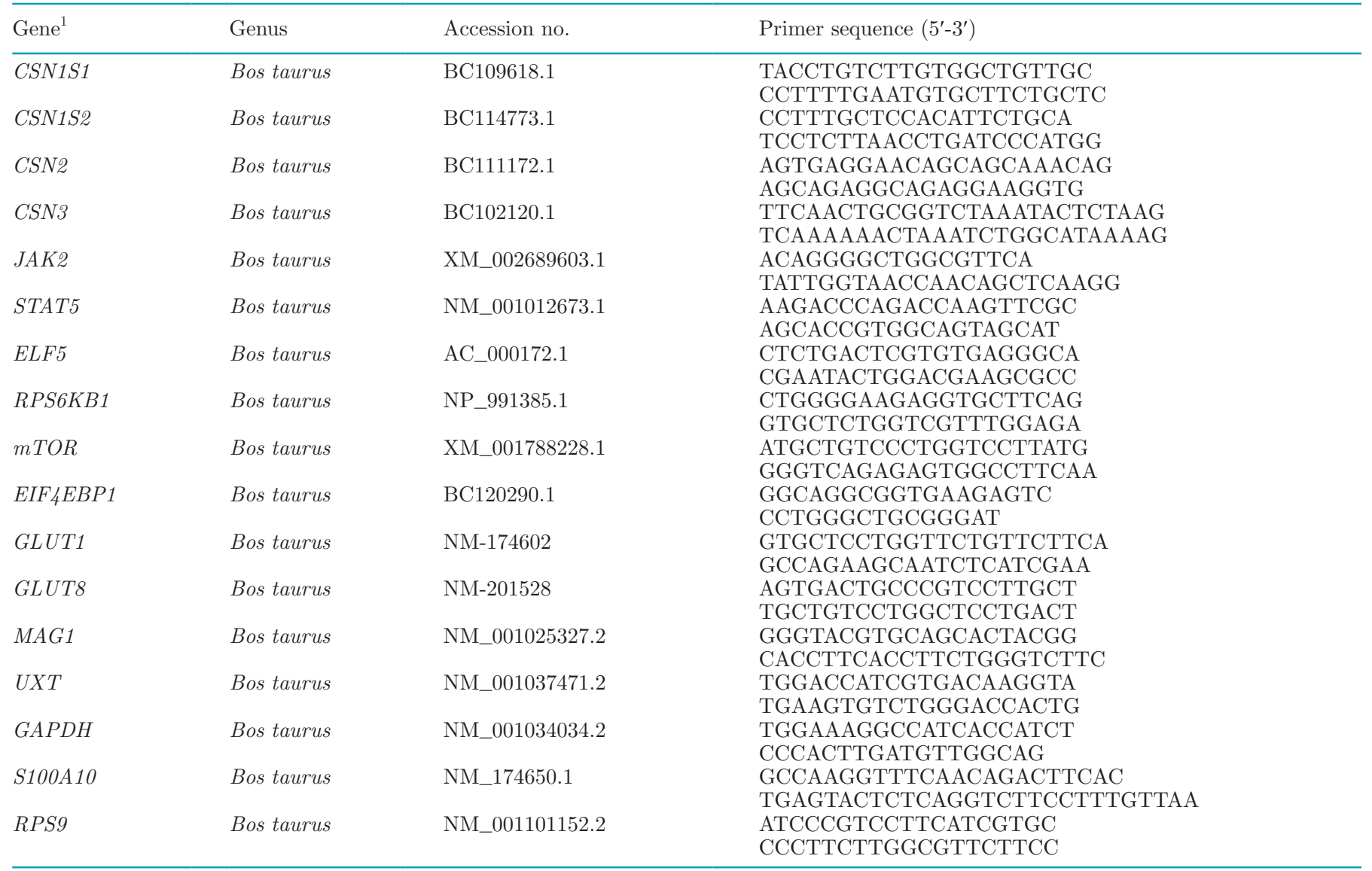

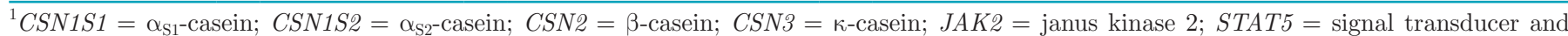
activator of transcription 5; ELF5 = E74-like factor 5; RPS6KB1 = ribosomal protein S6 kinase B1; $m$ TOR = mechanistic target of rapamycin; EIF $4 E B P 1=$ eukaryotic translation initiation factor $4 \mathrm{E}$ binding protein $1 ; G L U T 1=$ glucose transporter $1 ; G L U T 8=$ glucose transporter 8 ; $M T G 1=$ mitochondrial ribosome associated GTPase 1; UXT = ubiquitously expressed transcript isoform 2; GAPDH = glyceraldehyde 3-phosphate dehydrogenase; $S 100 A 10=\mathrm{S} 100$ calcium-binding protein A10; RPS9 = ribosomal protein S9.

ImmunoWay Biotechnology Co., cat. no. YP0575), and $\beta$-actin (ImmunoWay Biotechnology Co., cat. no. YT0099) were used, with $\beta$-actin acting as internal reference protein.

All data were statistically analyzed using SAS software (version 9.3, SAS Institute Inc., Cary, NC) and were representative of at least 3 independent experiments. The data are reported as least squares means \pm standard error of the mean. The MIXED procedure of SAS was used to analyze the effects of Lys/Met ratio and glucose level and their interaction (fixed effects) on cell viability, fractions of cells in different phases of cell cycle, relative mRNA and protein expression of casein and milk protein-related genes, and phosphorylation ratio of signaling protein genes. Differences were considered significant at $P<0.05$.

No interaction between Lys/Met ratio and glucose level on cell proliferation, cell cycle, and mRNA and protein abundance of genes involved in casein synthesis and regulation of casein synthesis was found $(P>0.06)$. The Lys/Met ratio and glucose level regulated casein biosynthesis through independent pathways. Treatment LM3.0 and a high level of glucose promoted the relative protein level of $\alpha_{\mathrm{S}_{1}}$-casein (2.1 vs. 1.3 times, respectively) and of $\beta$-casein (1.9 vs. 1.5 times, respectively; $P<0.05)$ compared with LM2.3 and the low glucose level, respectively (Figure 1). The high level of glucose and LM3.0 increased the relative expression of CSN1S1 $(P<0.01)$, whereas glucose $(P=0.18)$, in contrast to Lys/Met ratio $(P=0.04)$, did not affect the relative mRNA level of CSN2 (Table 2). Glucose level and Lys/ Met ratio did not significantly affect the mRNA levels of CSN1S2 and CSN3 $(P>0.15)$. The maximal casein synthesis response occurred when total concentration of Lys in the medium was $2 \mathrm{~m} M$ (Nan et al., 2014) or 7.48 $\mathrm{m} M$ (Gao et al., 2017) in the BMEC, and total concentration of Met in the medium occurred at $0.7 \mathrm{mM}$ (Nan et al., 2014) or $0.6 \mathrm{mM}$ (Qi et al., 2018) or even 1.17 
$\mathrm{m} M$ (Gao et al., 2017) in the BMEC. Arriola-Apelo et al. (2014) observed a curvilinear increase in casein fractional synthesis rate in bovine mammary tissue slices in response to several individual AA, with a predicted maximum response to Met at $0.10 \mathrm{~m} M$. These lower values reported by Arriola-Apelo et al. (2014) using tissue slices compared with the values obtained in cell cultures may be due to the difference in transport efficiency of AA between tissue culture and monolayer cell culture. The majority of the surface area of the mammary tissues exposed to cultural medium will be the basolateral membranes of secretory cells, whereas the apical membranes of cultured cells are normally exposed to incubation medium. This will lead to changes in the electrical potential of the mammary cells, which in turn will affect the activity of electrogenic transport systems (Shennan et al., 1997). In our study, the concentrations of Lys and Met added in the treatments were lower than those at peaked casein synthesis reported in the literature in the BMEC (Nan et al., 2014; Gao et al., 2017; Qi et al., 2018). The absolute concentrations of Lys and Met in LM3.0 were slightly lower than those in LM2.3. Given the slightly higher absolute Lys and Met concentrations in LM2.3 and the expected associated small increase in casein synthesis, the higher casein expression in LM3.0 indicated that the Lys/Met ratio does have an effect in addition to the effect of actual concentrations of Lys and Met in promoting casein synthesis, within the range of substrate levels in the present study. In accordance with these results, several studies indicated that an approximately 3:1 Lys/Met ratio in the MP of dairy cows could be the ideal profile to promote milk protein synthesis (NRC, 2001; Wang et al., 2010; Haque et al., 2012). We examined only 2 ratios of Lys/Met within the optimum concentration range. Whether the ratio changes under all concentration ranges of Lys and Met needs further study. Gao et al. (2017) found that the optimal combination of His, Lys, Met, and Leu for $\beta$-casein expression in the immortalized BMEC line has a 5:6:1:7 ratio of His:Lys: Met:Leu (5.47 mM His, $7.48 \mathrm{~m} M$ Lys, $1.17 \mathrm{~m} M$ Met, and $8.21 \mathrm{~m} M$ Leu) when the boundary levels for each individual AA concentration were His $(0.15-9.60 \mathrm{mM})$, Lys $(0.5-16.0 \mathrm{~m} M)$, Met $(0.12-4.32 \mathrm{~m} M)$, and Leu $(0.45-10.80 \mathrm{mM})$. Thus, within a certain concentration range (but not all concentration ranges), a 3:1 Lys/Met ratio will further promote casein synthesis.

The mRNA abundance of $J A K 2$ and E74-like factor 5 $(\boldsymbol{E L F 5})$ was 1.7 and 1.4 times greater $(P<0.01)$ with LM3.0 compared with LM2.3, respectively (Table 2); JAK2 can phosphorylate STAT5, which promotes transcription initiation of CSN1S1 and CSN2 by binding to specific promoter regions of casein genes (Clarkson et al., 2006; Yang et al., 2015). In addition, JAK2 acti- vates a series of signaling events involved in insulin receptor substrates followed by phosphoinositide 3-kinase and AKT1 (Harrington et al., 2005) and downstream activation of the mTOR pathway (Hayashi and Proud, 2007). This response was confirmed by the increased phosphorylation of mTOR $(P=0.02)$ in LM3.0 (Figure 1 ). However, the proportion of the role of JAK2 in activating mTOR needs further study. The ELF5 protein is crucial for expression of milk-related genes and can enhance STAT5 activity (Harris et al., 2006; Hennighausen and Robinson, 2008). The increase in JAK2 and ELF5 mRNA expression with LM3.0 might explain the increase in transcript abundances of CSN1S1 and CSN2, whereas the increase in mTOR $(P=0.04)$ protein expression and its phosphorylation $(P=0.02$; Figure 1) indicated a promoting role in the initiation of translation of $\alpha_{S_{1}}$-casein and $\beta$-casein synthesis. The ribosomal protein S6 kinase B1 (RPS6KB1) activates RPS6, which is part of the 40S ribosomal subunit and starts translation (Bionaz and Loor, 2011). Unphosphorylated eukaryotic translation initiation factor $4 \mathrm{E}$ binding protein 1 (EIF4EBP1) physically interacts with eukaryotic initiation factor $4 \mathrm{E}$ (eIF4E), thereby preventing protein synthesis. Phosphorylation of EIF4EBP1 releases eIF4E, which can direct ribosomes to the cap structure of mRNA to initiate their translation (Kimball and Jefferson, 2006). From our results, LM3.0 enhanced mRNA abundance of RPS6KB1 $(P<0.01)$ and reduced that of EIF $4 E B P 1(P<0.01$; Table 2$)$, which indicates stimulation of casein translation by inhibiting the assembly of eIF4E into the EIF4EBP1 complex and promoting activity of RPS6 downstream of mTOR.

In contrast to Lys/Met ratio, which did not influence cell viability and cell cycling $(P>0.15)$, the viability of BMEC was markedly increased in the presence of high glucose $(P<0.01)$, which confirms results from Zhao et al. (2012), who reported that the viability of BMEC increased with increasing glucose availability. High glucose level led to a decreased proportion of cells resting in the intermediate (G1) phase and an increased proportion of cells in the synthesis $(\mathrm{S})$ phase $(P<0.01$; Table 2). These results suggested a promoting role of high glucose on cell proliferation. However, a high glucose level decreased the mRNA abundance of GLUT8 $(P=0.03)$, which was not expected. The higher GLUT8 expression could be a compensatory mechanism for the low glucose availability at the low glucose level. Compared with a low glucose level $(2.5 \mathrm{mM})$, the higher dose $(17.5 \mathrm{mM})$ of glucose increased the expression of ELF5 1.1 times $(P=0.03$; Table 2$)$. This may explain the upregulation of CSN1S1 by high glucose. Compared with a low glucose level, a high level of glucose led to greater expression of total mTOR protein $(P<0.01)$ 
A
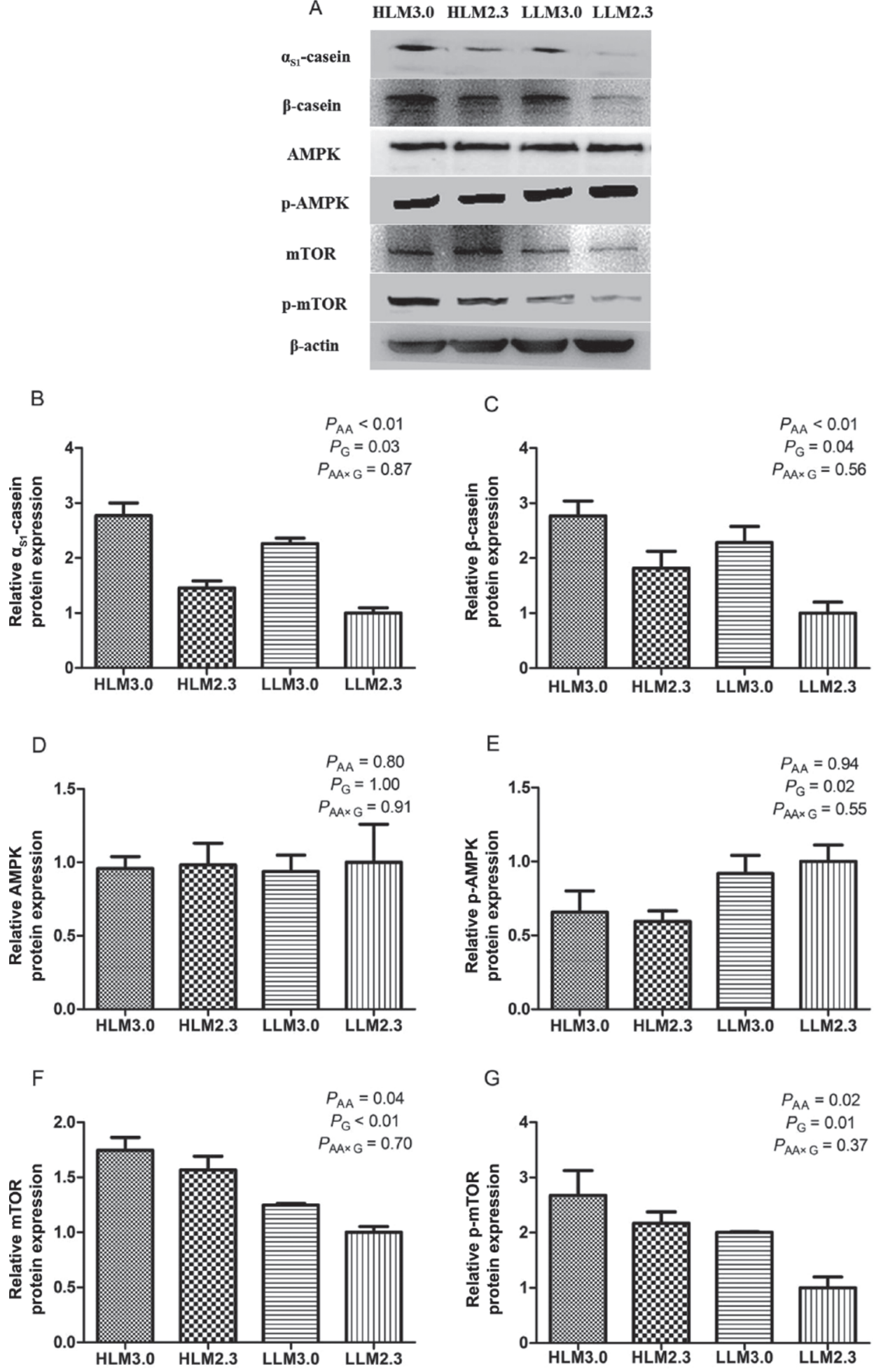

Figure 1. Effects of 36-h exposure of bovine mammary epithelial cells to Lys/Met ratios of 3:1 (1.2:0.4 $\mathrm{m} M, \mathrm{LM} 3.0 ;$ total AA = 8.24 mM) or 2.3:1 (1.4:0.6 $\mathrm{m} M$, LM2.3; total AA $=8.64 \mathrm{~m} M)$ and a glucose level of $17.5 \mathrm{~m} M$ (high, $\mathrm{H}$ ) or $2.5 \mathrm{~m} M$ (low, L) on the protein abundance of $\alpha_{\mathrm{S} 1}{ }^{-}$ casein (B), $\beta$-casein (C), AMPK (D), phosphorylated (p)-AMPK (E), mTOR (F), and p-mTOR (G). The protein levels come from cell lysates without proteins secreted into the medium. Panel A represents Western blots of $\alpha_{\mathrm{S} 1}$-casein, $\beta$-casein, AMPK, p-AMPK, mTOR, and p-mTOR with internal control $\beta$-actin in bovine mammary epithelial cells. Western blotting analyses were carried out on extracted proteins using specific antibodies. $\beta$-Actin was used as an internal reference protein to normalize protein expression. Relative optical intensities are quantified from the images and are expressed as fold over LLM2.3. mTOR = mechanistic target of rapamycin; AMPK = AMP-activated protein kinase; AA $=$ Lys/ Met ratio; $\mathrm{G}=$ glucose level. Error bars indicate SEM. 
and greater phosphorylation of both mTOR $(P=0.01)$ and AMPK $(P=0.02)$, whereas it did not affect total AMPK protein $(P=1.00$; Figure 1$)$; AMPK is a sensor of energy status and becomes phosphorylated when intracellular energy is low. Activated AMPK inhibits activity of mTOR and its downstream targets, which in turn may inhibit casein protein synthesis (Xu et al., 2012). Our results show that high glucose notably reduced phosphorylation of AMPK, which concomitantly removed the inhibitory effect on mTOR activity. Glucose level had a greater effect than Lys/Met ratio on phosphorylation of mTOR, but in contrast to Lys/Met ratio, the stimulatory effect of glucose on casein synthesis was not via transcriptional regulation of RPS6KB1 and EIF4EBP1. The greater effect of Lys/Met ratio compared with glucose level on $\alpha_{\mathrm{S1}^{-}}$casein (2.1 times vs. 1.3 times, respectively) and $\beta$-casein (1.9 times vs. 1.5 times, respectively) may indicate the importance of transcriptional regulation of RPS6KB1 and EIF4EBP1.

In summary, a Lys/Met ratio of 3:1 (1.2 mM Lys, 0.4 $\mathrm{m} M$ Met) and a high glucose level promoted $\alpha_{\mathrm{S}_{1}}$-casein and $\beta$-casein protein synthesis in BMEC. The effects of Lys/Met ratio and glucose level on casein synthesis and gene and protein expression were additive. Casein biosynthesis was regulated by glucose through promoting cell proliferation, accelerating cell cycle progression from the G1 phase to the S phase, and activating ELF5 and $\mathrm{AMPK} / \mathrm{mTOR}$ signaling pathways. In contrast, the Lys/Met ratio regulated casein synthesis via JAK2/ ELF5, mTOR, and its downstream RPS6KB1 and EIF4EBP1 signaling. Within the range of substrate levels in the present study, a change in Lys/Met ratio had a stronger effect on $\alpha_{\mathrm{S}_{1}}$-casein and $\beta$-casein abundance than a change in glucose level.

\section{ACKNOWLEDGMENTS}

This research was financially supported by the National Key Research and Development Program of China (2018YFD0501600; Beijing), the Program for Technology and Innovation of the Institute of Animal Sciences, Chinese Academy of Agricultural Sciences (ASTIP-IAS07; Beijing), the Beijing Dairy Industry Innovation Team (BAIC06-2019), and the Program for

Table 2. Effects of a 36-h exposure to different Lys/Met ratios (LM3.0 and LM2.3) and glucose levels [high (H) and low (L)] on bovine mammary epithelial cell viability, cell cycle, and mRNA abundance

\begin{tabular}{|c|c|c|c|c|c|c|c|c|}
\hline \multirow[b]{2}{*}{ Item } & \multicolumn{4}{|c|}{ Group $^{1}$} & \multirow[b]{2}{*}{ SEM } & \multicolumn{3}{|c|}{$P$-value ${ }^{2}$} \\
\hline & HLM3.0 & HLM2.3 & LLM3.0 & LLM2.3 & & $\mathrm{AA}$ & G & $\mathrm{AA} \times \mathrm{G}$ \\
\hline Optical density $590 \mathrm{~nm}$ & 1.58 & 1.51 & 0.89 & 0.82 & 0.119 & 0.63 & $<0.01$ & 0.98 \\
\hline Relative growth rate & 1.92 & 1.84 & 1.09 & 1.00 & 0.144 & 0.63 & $<0.01$ & 0.98 \\
\hline \multicolumn{9}{|l|}{ Cell cycle $^{3}(\%)$} \\
\hline G0/G1 & 72.58 & 71.03 & 76.60 & 76.65 & 0.948 & 0.15 & $<0.01$ & 0.13 \\
\hline \multicolumn{9}{|l|}{ mRNA abundance ${ }^{4}$} \\
\hline CSN1S1 & 1.67 & 1.19 & 1.41 & 1.00 & 0.096 & $<0.01$ & $<0.01$ & 0.49 \\
\hline CSN1S2 & 14.02 & 2.17 & 4.53 & 1.00 & 2.542 & 0.15 & 0.29 & 0.39 \\
\hline CSN2 & 2.51 & 1.01 & 1.48 & 1.00 & 0.263 & 0.04 & 0.18 & 0.19 \\
\hline CSN3 3 & 1.77 & 1.34 & 1.43 & 1.00 & 0.145 & 0.19 & 0.26 & 0.99 \\
\hline$J A K 2$ & 2.00 & 1.30 & 1.79 & 1.00 & 0.155 & $<0.01$ & 0.09 & 0.70 \\
\hline STAT5 & 1.93 & 1.30 & 1.37 & 1.00 & 0.153 & 0.09 & 0.13 & 0.58 \\
\hline GLUT8 & 0.85 & 0.72 & 0.95 & 1.00 & 0.047 & 0.51 & 0.03 & 0.20 \\
\hline
\end{tabular}

${ }^{1}$ Treatments were arranged in a $2 \times 2$ factorial design with a Lys/Met ratio of 3:1 (1.2:0.4 mM, LM3.0; total AA $\left.=8.24 \mathrm{~m} M\right)$ or 2.3:1 $(1.4: 0.6$ $\mathrm{m} M, \mathrm{LM} 2.3$; total $\mathrm{AA}=8.64 \mathrm{~m} M)$ and a glucose level of $17.5 \mathrm{~m} M$ (high, $\mathrm{H}$ ) or $2.5 \mathrm{~m} M$ (low, $\mathrm{L}$ ).

${ }^{2} \mathrm{AA}=$ Lys/Met ratio; $\mathrm{G}=$ glucose level.

${ }^{3}$ The cell cycle consists of 4 distinct phases: G1 phase (intermediate phase), S phase (synthesis), G2 phase (intermediate phase; G1, S, and G2 phase collectively known as interphase), and M phase (mitosis). Cells that have temporarily or reversibly stopped dividing are said to have entered a state of quiescence, called G0 phase.

${ }^{4}$ Data were normalized to the expression of RPS9, and values of LLM2.3 were arbitrarily set at 1.00. Data from 3 independent experiments are presented as LSM \pm SEM. CSN1S1 $=\alpha_{S 1}$-casein; CSN1S2 $=\alpha_{\mathrm{S} 2}$-casein; CSN2 $=\beta$-casein; CSN3 = -casein; JAK2 = janus kinase 2; STAT5 $=$ signal transducer and activator of transcription 5; ELF5 = E74-like factor 5; mTOR = mechanistic target of rapamycin; RPS6KB1 = ribosomal protein S6 kinase B1; EIF $4 E B P 1=$ eukaryotic translation initiation factor 4E binding protein 1; GLUT1= glucose transporter 1; GLUT8 = glucose transporter 8 . 
Leading Scientists of the Ten Thousand Talents (Beijing, China).

\section{REFERENCES}

Arriola Apelo, S. I., J. R. Knapp, and M. D. Hanigan. 2014. Invited review: Current representation and future trends of predicting amino acid utilization in the lactating dairy cow. J. Dairy Sci. 97:4000-4017.

Babar, M. E., M. Abdullah, A. Nadeem, and A. U. Haq. 2009. Prion protein gene polymorphisms in four goat breeds of Pakistan. Mol. Biol. Rep. 36:141-144.

Bionaz, M., and J. J. Loor. 2011. Gene networks driving bovine mammary protein synthesis during the lactation cycle. Bioinform. Biol. Insights 5:83-98.

Clarkson, R. W., M. P. Boland, E. A. Kritikou, J. M. Lee, T. C. Freeman, P. G. Tiffen, and C. J. Watson. 2006. The genes induced by signal transducer and activators of transcription (STAT) 3 and STAT5 in mammary epithelial cells define the roles of these STATs in mammary development. Mol. Endocrinol. 20:675-685.

Gao, H. N., S. G. Zhao, N. Zheng, Y. D. Zhang, S. S. Wang, X. Q. Zhou, and J. Q. Wang. 2017. Combination of histidine, lysine, methionine, and leucine promotes beta-casein synthesis via the mechanistic target of rapamycin signaling pathway in bovine mammary epithelial cells. J. Dairy Sci. 100:7696-7709.

Hadrová, S., L. Křǐžová, M. Richter, J. Třináctý, and M. Dračková. 2012. The effect of duodenal infusion of histidine on milk yield, milk composition, and plasma amino acids in dairy cows. J. Anim. Feed Sci. 21:555-565.

Hanigan, M. D., J. P. Cant, D. C. Weakley, and J. L. Beckett. 1998. An evaluation of postabsorptive protein and amino acid metabolism in the lactating dairy cow. J. Dairy Sci. 81:3385-3401.

Hanigan, M. D., L. A. Crompton, B. J. Bequette, J. A. Mills, and J. France. 2002. Modelling mammary metabolism in the dairy cow to predict milk constituent yield, with emphasis on amino acid metabolism and milk protein production: Model evaluation. J. Theor. Biol. 217:311-330.

Haque, M. N., H. Rulquin, A. Andrade, P. Faverdin, J. L. Peyraud, and S. Lemosquet. 2012. Milk protein synthesis in response to the provision of an "ideal" amino acid profile at 2 levels of metabolizable protein supply in dairy cows. J. Dairy Sci. 95:5876-5887.

Harrington, L. S., G. M. Findlay, and R. F. Lamb. 2005. Restraining PI3K: mTOR signalling goes back to the membrane. Trends Biochem. Sci. 30:35-42.

Harris, J., P. M. Stanford, K. Sutherland, S. R. Oakes, M. J. Naylor, F. G. Robertson, K. D. Blazek, M. Kazlauskas, H. N. Hilton, S. Wittlin, W. S. Alexander, G. J. Lindeman, J. E. Visvader, and C. J. Ormandy. 2006. Socs2 and elf5 mediate prolactin-induced mammary gland development. Mol. Endocrinol. 20:1177-1187.

Hayashi, A. A., and C. G. Proud. 2007. The rapid activation of protein synthesis by growth hormone requires signaling through mTOR. Am. J. Physiol. Endocrinol. Metab. 292:E1647-E1655.

Hennighausen, L., and G. W. Robinson. 2008. Interpretation of cytokine signaling through the transcription factors STAT5A and STAT5B. Genes Dev. 22:711-721.

Hu, H., J. Wang, D. Bu, H. Wei, L. Zhou, F. Li, and J. J. Loor. 2009. In vitro culture and characterization of a mammary epithelial cell line from Chinese Holstein dairy cow. PLoS One 4:e7636.
Kimball, S. R., and L. S. Jefferson. 2006. New functions for amino acids: Effects on gene transcription and translation. Am. J. Clin. Nutr. 83:500S-507S.

Livak, K. J., and T. D. Schmittgen. 2001. Analysis of relative gene expression data using real-time quantitative PCR and the $2^{-\triangle \Delta C T}$ method. Methods 25:402-408.

Nan, X., D. Bu, X. Li, J. Wang, H. Wei, H. Hu, L. Zhou, and J. J. Loor. 2014. Ratio of lysine to methionine alters expression of genes involved in milk protein transcription and translation and mTOR phosphorylation in bovine mammary cells. Physiol. Genomics 46:268-275.

Nichols, K., J. Dijkstra, H. Van Laar, S. Pacheco, H. J. Van Valenberg, and A. Bannink. 2019. Energy and nitrogen partitioning in dairy cows at low or high metabolizable protein levels is affected differently by post-rumen glucogenic and lipogenic substrates. J. Dairy Sci. 102:395-412.

Nichols, K., J. J. Kim, M. Carson, J. A. Metcalf, J. P. Cant, and J. Doelman. 2016. Glucose supplementation stimulates peripheral branched-chain amino acid catabolism in lactating dairy cows during essential amino acid infusions. J. Dairy Sci. 99:1145-1160.

NRC. 2001. Nutrient Requirements of Dairy Cattle. 7th rev. ed. Natl. Acad. Sci., Washington, DC.

Qi, H., C. Meng, X. Jin, X. Li, P. Li, and X. Gao. 2018. Methionine promotes milk protein and fat synthesis and cell proliferation via the SNAT2-PI3K signaling pathway in bovine mammary epithelial cells. J. Agric. Food Chem. 66:11027-11033.

Reynolds, C. K., D. L. Harmon, and M. J. Cecava. 1994. Absorption and delivery of nutrients for milk protein synthesis by portaldrained viscera. J. Dairy Sci. 77:2787-2808.

Rius, A. G., J. A. D. R. N. Appuhamy, J. Cyriac, D. Kirovski, O. Becvar, J. Escobar, M. L. McGilliard, B. J. Bequette, R. M. Akers, and M. D. Hanigan. 2010. Regulation of protein synthesis in mammary glands of lactating dairy cows by starch and amino acids. J. Dairy Sci. 93:3114-3127.

Shennan, D. B., I. D. Millar, and D. T. Calvert. 1997. Mammary-tissue amino acid transport systems. Proc. Nutr. Soc. 56:177-191.

Vandesompele, J., K. De Preter, F. Pattyn, B. Poppe, N. Van Roy, A. De Paepe, and F. Speleman. 2002. Accurate normalization of real-time quantitative RT-PCR data by geometric averaging of multiple internal control genes. Genome Biol. 3:RESEARCH0034.

Wang, C., H. Y. Liu, Y. M. Wang, Z. Q. Yang, J. X. Liu, Y. M. Wu, T. Yan, and H. W. Ye. 2010. Effects of dietary supplementation of methionine and lysine on milk production and nitrogen utilization in dairy cows. J. Dairy Sci. 93:3661-3670.

Xu, J., J. Ji, and X. H. Yan. 2012. Cross-talk between AMPK and mTOR in regulating energy balance. Crit. Rev. Food Sci. Nutr. $52: 373-381$.

Yang, J. X., C. H. Wang, Q. B. Xu, F. Q. Zhao, J. X. Liu, and H. Y. Liu. 2015. Methionyl-methionine promotes alpha-s1 casein synthesis in bovine mammary gland explants by enhancing intracellular substrate availability and activating JAK2-STAT5 and mTORmediated signaling pathways. J. Nutr. 145:1748-1753.

Zhang, M. C., S. G. Zhao, S. S. Wang, C. C. Luo, H. N. Gao, N. Zheng, and J. Q. Wang. 2018. D-Glucose and amino acid deficiency inhibits casein synthesis through JAK2/STAT5 and AMPK/ mTOR signaling pathways in mammary epithelial cells of dairy cows. J. Dairy Sci. 101:1737-1746.

Zhao, K., H. Y. Liu, H. F. Wang, M. M. Zhou, and J. X. Liu. 2012. Effect of glucose availability on glucose transport in bovine mammary epithelial cells. Animal 6:488-493. 